\title{
A prospective randomized controlled trial for comparison of oral misoprostol with methyl ergometrine in the third stage of labour for prevention of post-partum haemorrhage
}

\author{
Sushma Gore*, Atul Padmawar, Sabir Khan Pathan
}

Department of Obstetrics and Gynecology, Shri Vasantrao Naik Government Medical College, Yavatmal, India

Received: 21 May 2017

Accepted: 26 May 2017

*Correspondence:

Dr. Sushma Gore,

E-mail: sushmasarangtarak@gmail.com

Copyright: (C) the author(s), publisher and licensee Medip Academy. This is an open-access article distributed under the terms of the Creative Commons Attribution Non-Commercial License, which permits unrestricted non-commercial use, distribution, and reproduction in any medium, provided the original work is properly cited.

\begin{abstract}
Background: Near about $11 \%$ of women having live births have severe PPH (Globally 14 million women per year). About $3.9 \%$ of vaginal deliveries and $6.4 \%$ of cesarean section get PPH. Near about 1.4 million women die of PPH every year. Frequency of PPH is related to management of third stage of labour. Objective of the study was to compare the efficacy of misoprostol with conventional oxytocics for active management of third stage of labour.

Methods: The present study was carried out in tertiary care teaching hospital for a period of three years from June 2007-May 2010. A total of 364 study participants who reported to labour ward with labour pains in latent phase and subsequently went in spontaneous labour were enrolled and randomly distributed to two groups and given oral misoprostol and i.v. ergometrine.

Results: The mean age in Group A was $23.17 \pm 2.55$ and $24.31 \pm 3.28$ respectively. It was observed that most the study participants in both the groups had the duration of third stage of labour in between 10-14 minutes i.e. 29\% in Group A and $36.3 \%$ in Group B respectively. The duration of third stage of labour was significantly more in Group B compared to Group A.

Conclusions: Misoprostol is a promising drug in the management of third stage of labour for the prevention of postpartum haemorrhage.
\end{abstract}

Keywords: Management, Methyl ergometrine, Misoprostol, Postpartum haemorrhage

\section{INTRODUCTION}

Pregnancy and child birth involve significant health risks, even for women with no pre-existing health problems. Near about one quarter of all maternal deaths are due to haemorrhage: the proportion range from less than $10 \%$ to nearly $60 \%$ in various countries. ${ }^{1}$

It has been observed that near about $11 \%$ of women having live births have severe PPH (Globally 14 million women per year). About 3.9\% of vaginal deliveries and $6.4 \%$ of Cesarean section get PPH. Near about 1.4 million women die of PPH every year. Studies have showed that $15-25 \%$ of maternal deaths in India are due to $\mathrm{PPH}^{2}$ About $10 \%$ of obstetric hysterectomies are due to $\mathrm{PPH}$. In developing countries $\mathrm{PPH}$ is an important cause of maternal mortality and morbidity where about $28 \%$ are attributed due to this cause. ${ }^{3}$

Frequency of PPH is related to management of third stage of labour. Several controlled evaluations indicate that a policy of active management of third stage of labour can reduce the incidence of post-partum haemorrhage. The prophylactic use of oxytocics in the third stage of labour has been shown significant reduction in the risk of postpartum haemorrhage. ${ }^{4}$ The causes of $\mathrm{PPH}$ includes 
uterine atony $(65 \%)$ which is most common, genital tract trauma $33 \%$, retained placenta $27 \%$, coagulation disorders and uterine rupture. ${ }^{5,6}$

In developing countries where maternal mortality is high and resources are limited the introduction of low cost, evidence based practices to prevent and manage PPH Can improve maternal and infant survival. Recently use of misoprostol, an oral prostaglandin E1 analogue is effective in prevention of PPH. A double blinded randomized controlled trial done at tertiary care hospital showed that misoprostol is effective as oxytocin in prevention of $\mathrm{PPH}^{7}$ Some studies have shown that sublingual use of misoprostol is more effective than intravenous methyl ergometrine in prevention of $\mathrm{PPH}$.

In developing countries, we are still struggling to ensure provision of antenatal care to all pregnant women, safe home and hospital deliveries and timely referral to appropriate facilities to reduce maternal mortalities, the role of misoprostol being cheap, stable and easily administrable drug acts as an angel in prevention of $\mathrm{PPH}$ in third stage of labour.

\section{Aims and objectives}

To compare the efficacy of misoprostol with conventional oxytocics for active management of third stage of labour.

\section{METHODS}

The present study was carried out in tertiary care teaching hospital for a period of three years from June 2007-May 2010. A total of 364 study participants who reported to labour ward with labour pains in latent phase and subsequently went in spontaneous labour were enrolled and randomly distributed to two groups.

- 182 women in Group A received oral misoprostol

- 182 women in Group B received i.v. ergometrine

\section{Inclusion criteria}

Low risk pregnant women admitted in labour room with labour pains in latent phase and subsequently went into spontaneous labour.

\section{Exclusion criteria}

- Gestational age less than 37 years

- Hydramnios

- Antepartum haemorrhage

- Pre-eclampsia

- Multiple pregnancy

- Intrauterine fetal distress

- Coagulation disorders
- Case of Ashtma

- Epilepsy

- Heart disease

- Kidney disease

- Severe anemia with haemoglobin less than 7

- Patients with complicated or eventful first and second stage of labour.

\section{Methodology}

All the study participants were explained the purpose of the study. The study was conducted after taking permission from institutional ethical committee. A written consent was taken from all the participants. A detailed medical and obstetric history was taken and all routine antenatal investigations were done. All the vitals were monitored on admission as well as after delivery till day one post-partum.

- Group A was given 2 tabs of misoprostol orally(400ug) immediately after the delivery of the baby.

- Group B was given IV ergometrine(0,2mg) after delivery of anterior shoulder.

Placenta delivered by controlled traction along with uterine massage was given in both groups. Women were closely monitored during fourth stage of labour. The evaluation of blood loss was assessed by placing cotton pads under the buttocks prior to the delivery of baby. After the delivery of the placenta the total pads and linen used were weighed in grams. The weight of $1 \mathrm{gm}$ of cotton pad or linen was equal to $1 \mathrm{ml}$ (Langford 2000). From this the known dry weight subtracted and the calculated volume added.

\section{Statistical analysis}

Data was entered into Microsoft Excel and analyzed using simple proportions, mean, standard deviation and chi-square test.

\section{RESULTS}

The mean age in group $\mathrm{A}$ was $23.17 \pm 2.55$ and $24.31 \pm 3.28$ respectively. In Group A, maximum study participants were in social class-III (38\%) and in Group B maximum were in social class-II (36.3\%). In Group A, near about $69.2 \%$ were primigravida and in group B $60 \%$ were primigravida.

The mean fall in $\mathrm{Hb}$ percentage in Group A was 9.73 with standard deviation of 0.75 as compared to 9.43 with standard deviation of 0.73 in Group B. The difference in $\mathrm{Hb}$ percentage before and after in Group $\mathrm{B}$ was significant but it was not significant in Group A. Though the difference $\mathrm{Hb}$ on Group B was significant but it was in normal limits (Table 1). 
Table 1: Comparison of haemoglobin in both the groups.

\begin{tabular}{|llllll|}
\hline Groups & Number & $\begin{array}{l}\text { Haemoglobin }(\text { Mean } \pm \text { SD) } \\
\text { Before delivery }\end{array}$ & After delivery & P value & Results \\
\hline Group A (Misoprostol) & 182 & $9.77 \pm 0.76$ & $9.73 \pm 0.75$ & $\mathrm{P}>0.05$ & Not significant \\
\hline Group B (Ergometrine) & 182 & $9.91 \pm 1.08$ & $9.48 \pm 0.73$ & $\mathrm{P}<0.001$ & Significant \\
\hline
\end{tabular}

Table 2: Comparison of systolic and diastolic blood pressure in both the groups.

\begin{tabular}{|c|c|c|c|c|}
\hline \multirow{2}{*}{ Blood pressure } & \multicolumn{2}{|l|}{ Group A (182) } & \multicolumn{2}{|c|}{ Group B (182) } \\
\hline & SBP & DBP & SBP & DBP \\
\hline Before delivery & $109.04 \pm 6.52$ & $73.09 \pm 6.86$ & $111.3 \pm 7.65$ & $74.49 \pm 5.09$ \\
\hline After delivery & $110.23 \pm 6.78$ & $75.26 \pm 5.84$ & $114.40 \pm 8.02$ & $76.46 \pm 4.49$ \\
\hline$P$ value & $>0.05$ & $\mathrm{P}<0.05$ & $\mathrm{P}<0.05$ & $\mathrm{P}<0.05$ \\
\hline Result & Not significant & Significant & Significant & Significant \\
\hline
\end{tabular}

In both the groups there was change in both systolic and diastolic blood pressure after delivery, but the change was within acceptable limits (Table 2).

It was observed that most the study participants in both the groups had the duration of third stage of labour in between 10-14 minutes i.e. $29 \%$ in Group A and $36.3 \%$ in Group B respectively. The duration of third stage of labour was significantly more in Group B compared to Group A (Table 3).

Table 3: Comparison of duration of third stage of labour in both the groups.

\begin{tabular}{|lll|l|}
\hline $\begin{array}{l}\text { 3rd } \text { stage of } \\
\text { labour (minutes) }\end{array}$ & $\begin{array}{l}\text { Group A } \\
(\mathbf{1 8 2})\end{array}$ & $\begin{array}{l}\text { Group B } \\
(\mathbf{1 8 2})\end{array}$ & P value \\
\hline Range (minutes) & $3-5$ & $4-20$ & \\
\hline Mean \pm SD & $7.31 \pm 2.93$ & $8.28 \pm 2.83$ & $\mathrm{P}<0.01$ \\
\hline
\end{tabular}

It was observed that $47.8 \%$ in group A had blood loss of about $50-150 \mathrm{ml}$ which is more than Group B (29.1\%). Near about $44 \%$ in Group B study participants had blood loss of 151-250 which is more than Group A (33\%). Around about $30 \%$ of blood loss was $>250 \mathrm{ml}$ in Group B which is more than Group A (19.2). The findings show that more blood loss of seen in Group B (Table 4).

Table 4: Amount of blood loss in both the groups.

\begin{tabular}{|lll|}
\hline Blood loss $(\mathrm{ml})$ & Group A & Group B \\
\hline $50-150$ & $87(47.8)$ & $53(29.1)$ \\
\hline $151-250$ & $60(33)$ & $80(44.0)$ \\
\hline$>250$ & $35(19.2)$ & $49(26.9)$ \\
\hline Total & $182(100)$ & $182(100)$ \\
\hline
\end{tabular}

\section{DISCUSSION}

The mean age in group A was 23.31 and 24.31 respectively which is little less as a compared to similar studies carried out by Amant et al and $\mathrm{Ng}$ et al with mean age was 29.8 and 28.1 respectively. In the present study, the number of primigravida were higher than multigravida in Group A $(69.2 \%)$ and Group B (59\%) which is comparable with Amant et al $(51 \%)$ and $\mathrm{Ng}$ et al $(52.7 \%))^{8,9}$

In present study, the difference between haemoglobin status after 1 day post-partum in both groups A and B was $9.68 \pm 0.76$ and $9.23 \pm 0.83$ respectively. Similar studies conducted by various authors ${ }^{8,9,10}$ did not show any fall in haemoglobin level after one day post-partum. The mean fall in haemoglobin was more in group B (methylergometrine) compared to group A (misoprostol) and all these findings are comparable with other studies. It was observed that in present study there was low haemoglobin level after one day post-partum in both the groups and this is because the present study was conducted in rural area where poverty is the main problem and due to which there is lack of proper nutrition and awareness which leads to nutritional anemia and thus the haemoglobin status was low before delivery itself.

It was observed that most the study participants in both the groups had the duration of third stage of labour in between 10-14 minutes i.e. 29\% in Group A and 36.3\% in Group B respectively. There was a significant reduction in the duration of the third stage of labour in Group A than Group B. The present study findings were similar with other done by Amant et, $\mathrm{Ng}$ et al. ${ }^{8,9}$ In the present study significant reduction in the duration of third stage of labour was achieved inspite of minimal oral dose of misoprostol.

In present study, the amount of blood loss was little less in both the groups than other studies. As only low dose of misoprostol was used yet the amount of blood loss was within limits. The difference of blood loss in both the groups was statistically significant. Study done by Langenbah et al, showed that the amount of blood loss was more in methylergometrine group than in misoprostol group which is similar to present study. ${ }^{10}$ 


\section{CONCLUSION}

The present study concludes that misoprostol is a promising drug in the management of third stage of labour for the prevention of post-partum haemorrhage, especially in remote rural areas where facility for refrigeration and parenteral drug administration is not available. But in future there is a need to evaluate various routes and doses not only in low risk group but also in high risk group.

Funding: No funding sources Conflict of interest: None declared

Ethical approval: The study was approved by the Institutional Ethics Committee

\section{REFERENCES}

1. Abouzahr C. Antepartum and Post partum Haemorrhage. In: Murray CJL, Lopez AD, eds. Health dimensions of sex and reproduction. Boston: Harvard University Press.1998;3.

2. Smith JR, Barabara BG. Management of third stage of labour. Available at http:// emedicine.medscape. com/article/275304-media (cited 2016 Dec 12).

3. Smith JR. Post partum haemorrhage. Available at http://www.emedicine.com (cited 2016 Dec 12).

4. Vimala N, Mitthal S, Kumar S, Dadhwal V, Mehta S. Sublingual misoprostol versus methyergometrine for active management of the third stage of labour. Int J Gyneacol Obstet. 2004;87(1):1-5.

5. Rana S. Post partum haemorrhage in obstetrics and perinatal care for developing countries, Islamabad, Pakistan. Saf publications. 1998;1:1080-102.

6. Shaheen F, Jeen J. Post partum haemorrhage: Still a challenge. J Rawal Med Coll. 2003;7:77-81.

7. Kundodyiwaa TW, Majokoa F, Rusakanikob S. Misoprostol versus oxytocin in the third stage of labour. Int J Gyneacol Obstet. 2001;75(3):235-41.

8. Amant F, Splitz B, Timmerman D. Misoprostol compared with methylergometrine for the prevention of post partum haemorrhage: A double blind ramdomized trial. $\mathrm{Br} \mathrm{J}$ Obstet Gynaecol. 1999;106:1066-70.

9. $\mathrm{Ng}$ P S. A multicentric randomized controlled trial of oral misoprostol and im syntometrine in the management of the third stage of labour. Hum Reprod. 2001;16:31-5.

10. Langenbach C. Misoprostol in preventing post partum haemorrhage: a meta analysis. Int J Gynaecol Obstet. 2000;92:8-10.

Cite this article as: Agrawal S, Das V, Agarwal A, Pandey A. Fetal Doppler for prediction of adverse perinatal outcome in preeclampsia in a low resource setting. Int J Reprod Contracept Obstet Gynecol 2017;6:2825-8. 